\title{
A Rare Etiology of Chronic Polyradiculoneuropathy: IgD Multiple Myeloma
}

\author{
Fall Seynabou, El Hadji Daouda Niang*, Sarr Khadim, Diallo Alioune Badara, \\ Dieng Fatma, Camara Marième Lolita, Coba Christian, Dakono Aminata, \\ Ndiaye Awa, Ndiaye Fatou Samba Diago \\ Department of Clinical Hematology Dalal Jamm Hospital, Dakar, Senegal \\ Email: *elhadjidaoudaniang@gmail.com
}

How to cite this paper: Seynabou, F., Niang, E.H.D., Khadim, S., Badara, D.A., Fatma, D., Lolita, C.M., Christian, C., Aminata, D., Awa, N. and Diago, N.F.S. (2021) A Rare Etiology of Chronic Polyradiculoneuropathy: IgD Multiple Myeloma. Open Access Library Journal, 8: e7818.

https://doi.org/10.4236/oalib.1107818

Received: August 2, 2021

Accepted: August 27, 2021

Published: August 30, 2021

Copyright () 2021 by author(s) and Open Access Library Inc.

This work is licensed under the Creative Commons Attribution International License (CC BY 4.0).

http://creativecommons.org/licenses/by/4.0/

\begin{abstract}
Introduction: Immunoglobulin D multiple myeloma (IgD MM) is a rare entity of multiple myeloma (2\%), characterised by its clinical severity, renal presentation and poor prognosis. IgD myeloma remains an exceptional cause of chronic polyradiculoneuropathy. Observation: A 54-year-old patient, known to have type 2 diabetes since 2016, was admitted in December 2020 for non-febrile obnubilation associated with tetraparesis. The interrogation noted the occurrence of a motor deficit of the four limbs for 4 months in connection with a sensitivemotor polyradiculoneuropathy of the axon-myelin type of the four limbs. Glasgow's score was 10 . Blood pressure was $130 / 80 \mathrm{mmHg}$, pulse 116 beats/min, temperature $37^{\circ} \mathrm{C}, \mathrm{SaO}_{2} 92 \%$ on room air, low capillary blood glucose 1.08 and oliguria $70 \mathrm{cc} / \mathrm{H}$. The physical examination revealed meningeal syndrome, tetraparesis, anaemia and renal oedema. Investigations revealed severe hypercalcaemia $(140 \mathrm{mg} / \mathrm{L}$ ), purulent meningitis (purulent liquid CSF, $12.38 \mathrm{~g} / \mathrm{L}$ protein, $0.52 \mathrm{~g} / \mathrm{L}$ glycorrhaphy, $14 / \mathrm{mm}^{3}$ leucocytes, $2000 / \mathrm{mm}^{3}$ red blood cells) and acute renal failure $(74 \mathrm{mg} / \mathrm{L}$ creatinine, 5 $\mathrm{mL} / \mathrm{min} / \mathrm{m}^{3}$ GFR, $2.65 \mathrm{mg} / \mathrm{L}$ urea). Symptomatic IgD multiple myeloma was suspected on the basis of bone marrow plasmacytosis, bilateral frontal diploid lacunar osteolysis on CT scan and IgD positivity. Conclusion: Our observation illustrates the possible plurality of symptoms of $\operatorname{IgD} \mathrm{MM}$, particularly chronic polyradiculoneuropathy which is a rare neurological sign that should not be ignored in order to avoid diagnostic errors.
\end{abstract}

\section{Subject Areas}

Neurology

\section{Keywords}

Immunoglobulin D, Multiple Myeloma, Polyardiculoneuropathy 


\section{Introduction}

Immunoglobulin $\mathrm{D}$ multiple myeloma $(\operatorname{IgD} \mathrm{MM})$ is a rare entity of multiple myeloma ( $2 \%$ of $\mathrm{MM})$, characterised by its clinical severity, its mode of onset often in the setting of renal failure (RF) and its poor prognosis (11) [1]. Nervous system involvement is rarely described in IgD myeloma. We report an observation of IgD MM in which chronic polyradiculoneuropathy was also an inaugural symptom.

\section{Observation}

This was a 54-year-old patient, known type 2 diabetic on metformin, referred on 10/12/2020 to the Clinical Haematology Department of Dalal Jamm Hospital for non-febrile obnubilation associated with tetraparesis.

Questioning of the family revealed a motor deficit in all four limbs, with a progressive, asymmetrical onset over a period of four months, and diffused bone pain, more marked in the right upper limb. An electroneuromyography (ENMG) was in favour of a severe sensitivomotor polyradiculoneuropathy of the axonomotor type in all four limbs, predominantly in the lower limbs.

On admission, the general examination noted altered consciousness with a Glasgow score of 10, pallor of the mucous membranes and oedema of the lower limbs associated with facial puffiness. Blood pressure was $130 / 80 \mathrm{mmHg}$, pulse 116 beats $/ \mathrm{min}$, temperature $37^{\circ} \mathrm{C}, \mathrm{SaO}_{2} 92 \%$ on room air, diuresis $70 \mathrm{cc} / \mathrm{H}$, capillary blood glucose 1.08 .

The neurological examination revealed a meningeal syndrome associating neck stiffness with Kurning's and Brudzinski's signs; tetraparesis, grade 2 buttock sores.

The locomotor examination noted pain on mobilisation of the left arm without local changes. The examination of the other apparatus was unremarkable.

The biological explorations carried out in emergency showed a severe normocytic normochromic anaemia (haemoglobin: 7 g/dL; VGM: 95 fl; MCHF: 34.5\%; TR: $57 \mathrm{~g} / \mathrm{L}$ ), hyperleukocytosis at $11.39 \mathrm{G} / \mathrm{L}$, normal platelet count at 187 $\mathrm{G} / \mathrm{L}$, severe hypercalcaemia with corrected calcaemia at $140 \mathrm{mg} / \mathrm{L}$ and impaired renal function (creatininaemia at $74 \mathrm{mg} / \mathrm{L}$, GFR at $5 \mathrm{~mL} / \mathrm{min} / \mathrm{m}^{3}$, urea at 2.65 $\mathrm{mg} / \mathrm{L}$ ), without ionic disturbances (natraemia at $143.7 \mathrm{mEq} / \mathrm{L}$, kalaemia at 4.3 $\mathrm{mEq} / \mathrm{L}$, blood chloraemia at $115.7 \mathrm{mEq} / \mathrm{L}$ ). Fasting blood glucose was $0.8 \mathrm{~g} / \mathrm{L}$ and C-reactive protein $96 \mathrm{mg} / \mathrm{L}$. The lumbar puncture performed in the absence of contraindication to cerebral CT returned a purulent fluid with proteinorachy of $12.38 \mathrm{~g} / \mathrm{L}$, a glycorachy of $0.52 \mathrm{~g} / \mathrm{L}$, leukocytes of $14 / \mathrm{mm}^{3}$ and red blood cells of $2000 \mathrm{~mm}^{3}$, without germs or yeats on bacteriological examination. The patient was given zoledronic acid $4 \mathrm{mg}$ as an emergency.

Serum protein electrophoresis showed a monoclonal peak in the beta globulin region (Figure 1). Serum immunoelectrophoresis revealed a monoclonal immunoglobulin of the IgD lambda light chain type. The diagnosis of symptomatic $\mathrm{MM}$ was based on $68 \%$ bone marrow plasmacytosis and the presence of suspicious 


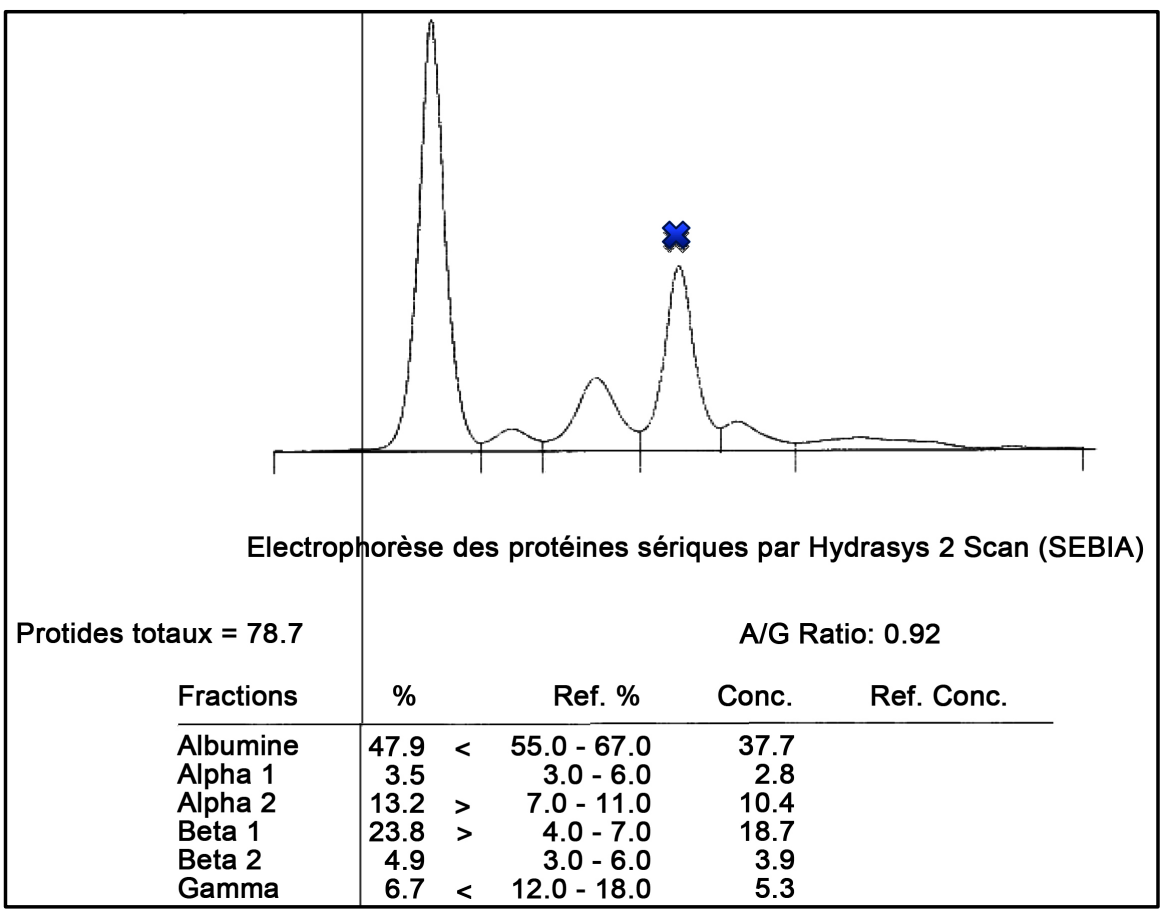

Figure 1. Serum protein electrophoresis (SPE). We note the presence of a monoclonal peak in the beta globulin area

bilateral frontal diploid osteolytic lacunar lesions without focal brain lesions (Figure 2) and on the arm. The disease was classified as stage IIIB according to the classification of SALMON and DURIE.

On medical imaging, the abdominal ultrasound was normal, showing normal-sized kidneys with good cortico-medullary differentiation. MRI of the spinal cord revealed, in addition to the multivertebral osteolysis lesions, an epiduritis compressing the dural sheath opposite L2-L3 and L4 (Figure 3).

The patient was treated symptomatically with zoledronic acid, haematological revival with packed red blood cells, analgesics, local care and antibiotic therapy with ceftriaxone injection. Dialysis was not available, and the patient died with severe uraemia.

\section{Discussion}

IgD myeloma is rare, representing $1 \%$ to $2 \%$ of myelomas [1]. In Senegal, to our knowledge, no case of IgD myeloma has been reported so far [2]. It generally occurs in young people, at the age of 54 years in our patient; whereas multiple myeloma occurs at an average age of 65 years [3]. The average age of onset of IgD myeloma is around 58 years [4]. A male predominance has been reported in the literature [5]. Extraosseous manifestations are common [5] [6]. One of the particularities of our patient is the neurological involvement marked by the occurrence of a chronic polyradiculoneuropathy (PRNC). The clinical picture of PRNC is essentially marked by the onset of a sensory-motor deficit over more than a month, usually in the lower limbs, and the deficits are often asymmetric 


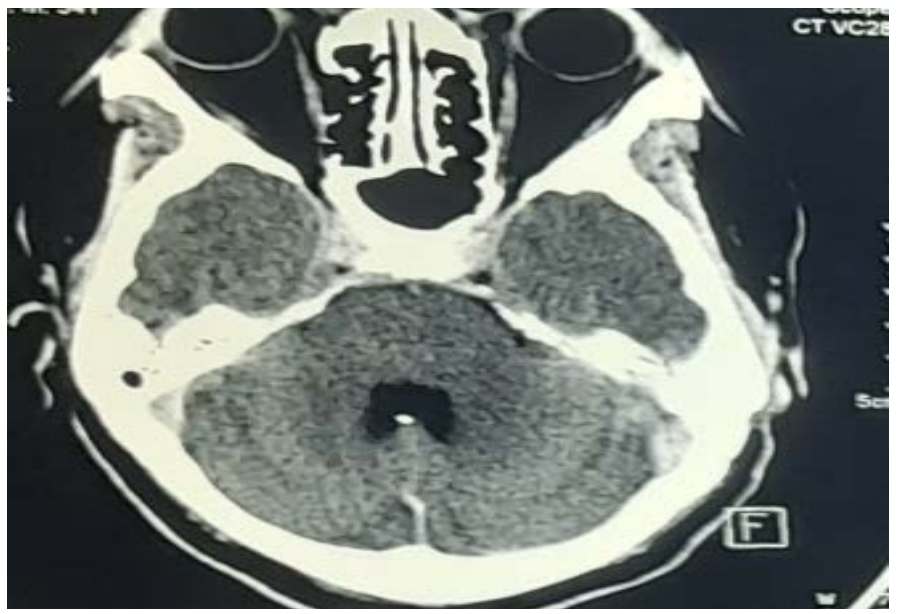

Figure 2. Cerebral CT scan. Suspicious bilateral frontal diploid lacunar osteolytic lesions without focal brain lesions.

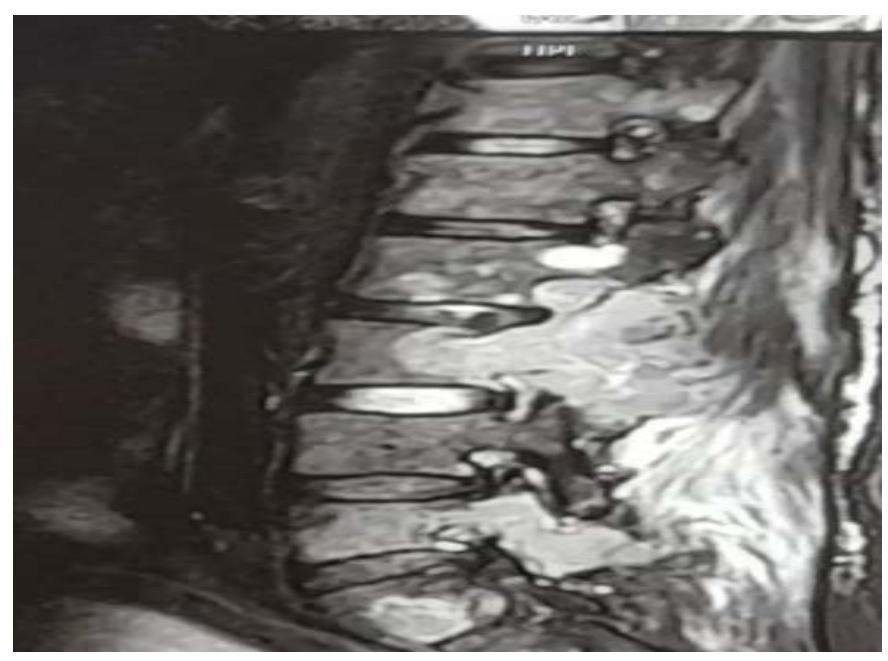

Figure 3. Spinal cord MRI. Multiple vertebral geodes and epiduritis compressing the dural sheath opposite L2-L3 and L4.

[7]. In our patient, a diagnostic delay of 4 months was noted with an asymmetric motor symptomatology. Reflexes may be abolished in all four limbs or only in the achilles. In addition to IgD multiple myeloma, our patient had type 2 diabetes which was responsible for neurological complications. However, diabetes is not a known major risk factor for PRNC. Thus, the association of diabetes with PRNC may be incidental [8]. This observation imposes a systematic etiological search for PRNC in all diabetics, especially those with multiple myeloma. This was done in our patient who had IgD MM. Serum protein electrophoresis is a referral test that often shows a monoclonal peak in the alpha $(\alpha)$ or beta $(\beta)$ globulin areas in 13\% - 20\% of IgD MM [9]. A monoclonal peak in the beta globulin area was found in our patient. Immunoelectrophoresis revealed the isotype which is frequently a lambda IgD type, as in our patient. In contrast to other isotypic forms of MM where $\kappa$ light chains predominate, $60 \%$ of IgD MM are associated with lambda light chains [9]. The predominance of $\lambda$ light chains 
could be explained by rearrangements in the immunoglobulin genes in which a $\mathrm{C} \mu$ deletion occurs preferentially in cells producing $\lambda$ light chain immunoglobulins [10]. The other neurological involvement observed is epiduritis compressing the dural sheath opposite L2-L3 and L4 due to an extension by contiguity of an adjacent bone involvement in the epidural space. Isolated epiduritis without bone involvement remains exceptional. In our patient, numerous secondary multivertebral lesions were found.

The purulent, sterile, pauci cellular meningoencephalitis observed in our patient leads to the discussion of myelomatous meningitis revealed by headaches, VI paralysis [11] more described in the course of IgA MM in the advanced stage of the disease. The diagnosis of decapitated infectious meningoencephalitis can be made in view of the immunosuppression and the initiation of antibiotic therapy before admission to our department. The increase in C-reactive protein is part of a non-specific biological inflammatory syndrome linked to the synthesis of interleukin 6 (IL-6), produced in large quantities by the tumour microenvironment [12].

In addition to neurological involvement, renal failure $(\mathrm{RF})$ is a fairly frequent mode of revelation of IgD MM, as noted in our patient who had stage 5 chronic kidney disease. Renal involvement is more frequent in $\operatorname{IgD}$ MM (52\%) than in IgA MM (17\%) and IgG MM (16\%). This frequency is probably related to the presence in the serum of an excess of light chains, especially of the lambda type, which are thought to be more nephrotoxic than kappa light chains [13]. Renal damage is a factor of morbidity and mortality in our practices. Renal dysfunction may be favoured by other factors, such as hypercalcaemia. The latter was found in our patient with a severe calcemia of $140 \mathrm{mg} / \mathrm{L}$. Hypercalcaemia is a relatively frequent biological sign in IgD MM [14] and may be indicative of the disease in $22 \%$ of cases [15].

\section{Conclusion}

Our observation illustrates the possible plurality of symptoms of IgD MM, particularly chronic polyradiculoneuropathy which is a rare neurological sign that should not be ignored in order to avoid diagnostic errors.

\section{Conflicts of Interest}

The authors declare no conflicts of interest.

\section{References}

[1] Mechtoune, M., Lahlimi, F.Z. and Tazi, I. (2021) Le myélome multiple à IgD: À propos d'un cas. PAMJ-Clinical Medicine, 6, Article No. 4. https://doi.org/10.11604/pamj-cm.2021.6.4.29094

[2] Fall, S., Dieng, F., Diouf, C., Djiba, B., Ndao, A.C. and Ndiaye, F.S.D. (2017) Profil diagnostique et évolutif du myélome multiple au Sénégal: Étude monocentrique de 2005 à 2016. Pan African Medical Journal, 8, Article No. 262.

https://doi.org/10.11604/pamj.2017.27.262.13164 
[3] Kapoor, P., Rajkumar, S.V., Dispenzieri, A., Gertz, M.A., Lacy, M.Q., Dingli, D., et al. (2011) Melphalan and Prednisone versus Melphalan, Prednisone and Thalidomide for Elderly and/or Transplant Ineligible Patients with Multiple Myeloma: A Meta-Analysis. Leukemia, 25, 689-696. https://doi.org/10.1038/leu.2010.313

[4] Benchekroun, L., Ouzzif, Z., Bouabdillah, M., Jaouhar, N., Aoufir, F., Aoufi, F., et al. (2011) Multiple Myeloma with D Immunoglobulin. Annales de Biologie Clinique, 69, 581-587. https://doi.org/10.1684/abc.2011.0617

[5] Chakri, I. and Benchekroun, L. (2018) Myélome à IgD révélé par une insuffisance rénale: À Propos d'un cas. Journal Marocain des Sciences Médicales, 22, No. 1. https://doi.org/10.48401/IMIST.PRSM/jmsm-v22i1.17269

[6] Amine, B., Benbouazza, K., Harzy, T., Rahmouni, R., Guedira, N., Lazrak, N., et al. (2004) Le myélome multiple à Ig D Kappa: Une nouvelle observation. Revue du Rhumatisme, 71, 617-619. https://doi.org/10.1016/j.rhum.2003.05.004

[7] Said, G. (2006) Chronic Inflammatory Demyelinating Polyneuropathy. Neuromuscular Disorders, 16, 293-303. https://doi.org/10.1016/j.nmd.2006.02.008

[8] Moussaid, R., El Mokhtari, M., Amjad, M. and Chraibi, A. (2014) Polyradiculonévrite chronique inflammatoire et neuropathie diabétique: Difficulté diagnostic et de prise en charge thérapeutique à propos d'un cas. Annales d Endocrinologie, 75, Article 376. https://doi.org/10.1016/j.ando.2014.07.354

[9] Poncet, J.C., Toussirot, E. and Wendling, D. (1997) Particularité du myélome à Immunoglobuline D. Revue du Rhumatisme, 64, 483-487.

[10] Bartoloni, C., Flamini, G., Logroscino, C., Guidi, L., Scuderi, F., Gambassi, G., et al. (1980) IgD “No Secretory” Multiple Myeloma: Report of a Case. Blood, 56, 898-901. https://doi.org/10.1182/blood.V56.5.898.898

[11] Afanasiev, V., Pottier, C., Benramdane, R., Precupanu, C., Cosma, D., Poll, R., et al. (2014) Méningite myélomateuse: Complication neurologique d'un myélome multiple. Revue Neurologique, 170, A64. https://doi.org/10.1016/j.neurol.2014.01.187

[12] San Miguel, J.F., Blade Creixenti, J. and Garcia-Sanz, R. (1999) Treatment of Multiple Myeloma. Haematologica, 84, 36-58. https://doi.org/10.3324/\%25x

[13] Alcalay, M., Gombert, J., Frocrain, C. and Bontoux, D. (1975) Le myeloma IgD. À propos d'un cas. La semaine des hôpitaux, 51, 1227-1234.

[14] Mayeur, D., Gruyer, P., Jarreau, C. and Dubrujeaud, J. (1992) Hypercalcémie révélatrice d'un myélome à IgD. La Presse Médicale, 21, Article No. 1774.

[15] Bataille, R., Boccadoro, M., Kein, B., Durie, B. and Pileri, A. (1992) C-Reactive Proteinand $B 2$ Microglobulin Produce a Simple and Powerful Myeloma Staging System. Blood, 80, 733-737. https://doi.org/10.1182/blood.V80.3.733.733 